\title{
Financial Innovation and Sustainable Development in Selected Countries in West Africa
}

\section{Folorunsho M. Ajide}

\begin{abstract}
Financial innovation has given a new trend to modern financial system and its importance has been widely recognized. This study investigated the effect of financial innovation augmented with bank competition on sustainable development in eight West African countries. Data were sourced from World Bank development indicators from years 2000-2013. We used two proxies of competitions, two proxies of financial innovations and regressed them on a growth indicator as well as development indicator with other control variables. Using panel data estimations, our results confirmed that an increase in banking efficiency driven by competition and financial innovation would improve economic growth and development. While the two proxies of competition were significant, the financial innovations were not significant; one displayed a negative, while the other exhibited a positive relationship with development. These results revealed the differential effects of different financial innovations adopted in the financial system. That is, the growth effect of financial innovation is sensitive to the choice of proxy. A reduction in demand for money caused by financial innovations could deter economic growth and development. This is because individuals would move away from more liquid assets to less liquid assets. On the other hand, financial innovations could potentially lead to an increase in money demand if payment systems improve and individual's demand for more liquid assets is channeled to productive sectors. We therefore concluded that policies which would drive competition and efficiency in the banking industry as well as financial innovation should be introduced to ensure effective functioning of the financial system.
\end{abstract}

Keywords: financial innovation, competition, development, Africa.

\section{INTRODUCTION}

A debate on financial innovation and its effect on growth and development can be traced to the view of Schumpeter (1934). He was the first to give

1 Folorunsho M. Ajide, Department of Economics, Southwestern University, Nigeria. KM 20, Sagamu-Benin Expressway, Okun Owa, PMB 2088,ljebu Ode, Ogun state, Nigeria, e-mail: ajide2010@gmail.com. 
us an idea of the connection between innovation performance of an economy and the functioning of its credit and capital markets. A good understanding of the relationship between finance, innovation, and growth begins with understanding the character of innovation. (Mazzucato, 2013). Financial innovation is perceived to be strategic by nature. It has value if its sustainability can be assured in the financial sector (Costanzo, Keasey \& Short, 2003). It is necessary to identify the kind of financial innovations which are associated with different development processes in terms of activities, formality and cross-functional involvement as well as performance outcomes. The connection between the financial sector and sustainable development is financial innovation. Financial innovation constitutes the introduction and promotion of financial products and services, the development of new processes, as well as the interaction with customers and the development of new structures for financial institutions (Mention, 2011). Innovation continues to play a key role as a force for sustainable development, social inclusion and peace, because of its potential to generate intangible and tangible social changes. It can reduce the gap of competitiveness, and uneven knowledgegap between the developed and developing countries (Salas, 2009).

This paper is a contribution to the empirics of financial innovation and economic growth and development in Africa. Although a substantial amount of academic research has been devoted to financial development and growth nexus, the overall effects of financial innovation on growth and development are not conclusive. The paper examines the effect of bank competition and financial innovation on sustainable development. This is based on the realization that effective competition in the banking industry can increase the level of financial innovation, reduce the cost of financial intermediation, improve delivery of high quality services and enhance consumers' welfare (Simpasa, 2013). Competition can be seen as a stimulus to increase downward pressure on costs of services or products, reduce managerial laziness and even improves the level of technology and financial innovation (Nickell, 1996). Thus, competition may have the desirable effect of stimulating technological research and development. It forces producers to innovate constantly in order to be efficient and effective in the production of higher quality products and minimize costs to maintain or increase their market share and make more profit (Motta, 2004; Whish, 2005; Ajide \& Ajileye, 2015).

Bank competition and financial innovation, as argued, in this paper, is a crucial instrument of the shifts towards sustainable development. It would be impossible or otherwise, without finance to foster the technological shift, and the pace of change towards sustainable development and growth would simply not be quick enough. The world is not short of savings, nor is it short of the needed technological investments and opportunities to redirect it to; if 
we are to avert the disastrous ongoing speed of global warming and its tipping points. Financial innovations and the role of the state in fostering these shifts worldwide is what the challenge is all about (Dasgupta, 2015).The possibility for innovation is full of challenges and opportunities. It is now necessary to create more awareness of the complex world in which we are living today, and the implications for saving tomorrow's planet, by helping governments, corporates and society to draft spurring sustainable polices and efforts.

In West Africa, competition and innovations in the banking sector have indeed increased over the period. New products such as international fund transfers, school fee loans, negotiable certificates of deposit, car loans, consumer/hire purchase loans, travellers' cheques, computerization of all transactions and branch networking have taken new shapes in terms of development. West African banks have both national and international networks and branches. Bank operations and information processing have vastly increased. Automated teller machines (ATMs) are now widespread, giving clients/customers the freedom to transact business at their own convenience. The current trend is for personal computer banking systems, telephone banking systems, e- banking, branchless banking, agent banking and, more importantly, SMS banking. These are driven by the improvement in telecommunication networks and advancement in computer technology in West African countries (Abor, 2005). It is now necessary to investigate whether financial innovations promote growth and development.

Following this background, we contribute to the existing literature by investigating the effect of bank competition and financial innovations on growth and sustainable development in West African countries. Our study investigates whether financial innovations are tailored towards productive sectors, hence economic growth in West Africa. We also investigate whether financial innovation and bank competition can foster economic growth by focusing on the peculiarity of the West African region. Policy makers really need to know if competition or higher market power is desirable in the West African banking industry, leading to improvements in financial innovation, and hence growth and development. The rest of this paper is organized into four sections. Section 2 deals with the literature review; section 3 discusses methodology while section 4 analyzes the results. Section 5 concludes the paper.

\section{LITERATURE REVIEW}

\section{Innovations in the African financial market and its growth}

The African financial market registered a growth rate of over $5 \%$ between 2003 and 2007, which had systematically exceeded the world average. This growth 
was stimulated by an important set of financial reforms. They were also the consequence and the driver of historically high levels of inflows and domestic resources (Dahou, Omar \& Pfister, 2009). In 2008, when the financial crisis hit Africa, the Continent was on the rise to have a stronger financial system. It was believed that strong financial markets were a prerequisite for innovation on the continent. While from the firms' perspective banks offer inadequate products (with high interest rates, large collateral requirements, and short repayment periods, among others), equity markets remain underdeveloped with only a low number of investors. Stock markets are limited in size and liquidity which can largely be explained by the lack of market culture, high listing costs, and ineffective investor protection. Therefore, there is a need for innovations in the system.

Innovation represents the changes in the process of ideation, evaluation, selection, development, and implementation of new or improved products, services, or programs with the purpose of increasing the number of ideas, improving the quality of ideas and a more efficient implementation of quality ideas. Financial innovation may be described as the emergence of new financial instruments and services, and of new forms of organization in more sophisticated and complete financial markets. Financial innovation is concerned with the introduction of new financial instruments or service or practice. That is, introducing new uses of funds, or finding out new sources of funds, or introducing new processes or techniques to handle day-to-day operations, or carrying out a re-organization on parts of existing financial institutions and channels. In addition, the emergence and the spectacular growth of new financial institutions and markets is also part of financial innovation (Patrya, 2006). Financial innovations include a range of changes in the financial system which results in the broadening, deepening, diversification, structural transformation, internationalization and sophistication of the financial system. They result in the financialization of the economy whereby the financial assets to total assets ratio tends to increase. Financial innovation concerns the introduction of new liquid assets that partially replace traditional money in agent's portfolios, technological progress in banking services that reduces the costs of transactions, and changes in the regulatory environment that facilitate transactions (Melnik \& Yashiv, 1994). It is believed that financial innovation has brought a permanent change to the money demand that is not caused by opportunity cost (i.e. interest rates and scale variables such as GDP) and it includes both technological processes and financial regulation or deregulation (Arrau \& De Gregorio, 1991).

Changes are taking place in the African financial system. The spread of mobile phones has accelerated the use of mobile phone financial services. 
This is because the number of mobile users has increased rapidly over the years, causing, significantly, the number of bank customers in many African countries to increase at a geometric rate. It was reported that Africa is currently leading the trend of mobile financial services with over 56 deployments in place. Sub-Saharan Africa alone accounts for over $45 \%$ of the world's total mobile money deployments. A survey conducted in June 2011 shows that East Africa has become the most active mobile money market in the World with $46 \%$ of all mobile money transactions processed in June 2011 originating from the African regions (African Development Bank, 2013).

Among the financial innovations that have taken place in the region are mobile financial services. These services include sending money, paying bills, receiving bulk payments and purchasing airtime. They are called functional transactions and are different from cash conversion or administrative transactions. The growth of mobile financial services in Africa has allowed millions of people, who would otherwise have been excluded from the formal financial system, to perform financial transactions relatively cheaply, securely, and reliably (Demirgüç-Kunt \& Klapper, 2012). Table 1 show that East Africa has the highest mobile money usage with about $0.38 \%$, even more than the world usage, while Southern Africa has the highest credit card usage in the region.

Table 1. Mobile money and credit cards usage in Africa

\begin{tabular}{lll}
\hline & Adults using Mobile Money(\%) in the past years & Adults with a Credit Card(\%) \\
\hline World & 0.05 & 0.15 \\
Africa & 0.14 & 0.03 \\
Central Africa & 0.08 & 0.02 \\
East Africa & 0.38 & 0.03 \\
North Africa & 0.03 & 0.03 \\
Southern Africa & 0.09 & 0.07 \\
West Africa & 0.09 & 0.01 \\
\hline
\end{tabular}

Source: Demirgüç-Kunt \& Klapper (2012).

The most familiar financial innovations adopted in African countries are ATMs and Point of Sale (POS). They are categorized as the most essential elements for financial service delivery. These services ensure efficient payment and settlement systems are in place. In some African countries, Demirgüç-Kunt and Klapper (2012) stated that the number of ATMs and POS still remains limited. For example, in 2010, Botswana counted 21 ATMs and 288 POS terminals per 100000 people while in South Africa the number of ATMs and POS stood at 52 and 700, respectively. 
However, with the high reduction in the cost of hardware and other supporting infrastructures, the new trend shows that the number of ATMs and POS has been growing at a fast pace in sub-Saharan Africa. It accounts for the second highest figure in the world after South Asia. The advent of internet banking has also improved the level of financial services in Africa. It has empowered different organizations with new business models and new ways to offer 24 hour accessibility to their customers. A significant achievement has been recorded in the payment and settlement systems. The Automated Clearing House, as observed in the system, has reduced the number of days its takes to clear quasi-money such as cheques. Another trend of innovation in the financial system is the introduction of crowdfunding, or the collective pooling of small resources (usually online) to finance projects. This can be taken as a financing model for innovative firms worldwide but Africa lags behind. Between 2011 and 2012, the crowdfunding model saw a growth rate of $91 \%$ worldwide to reach USD 2.8 billion (Econsultancy, 2012). There are two approaches to the model: Equity and lending-based crowdfunding where returns are expected as per typical investments, and donation and rewardbased crowdfunding which are mostly used for cause-based campaigns. Africa however only hosts less than $1 \%$ of total crowd sourcing platforms, and about $0.5 \%$ of total crowd funding campaigns worldwide (Econsultancy, 2012).

Also, in most African countries, financial derivates activity does not exist. While the derivates market in South Africa still remains under developed, there is no interest rate or cross currency swap market in Algeria, Nigeria and Zimbabwe. However, there are a few off-shore non-capital markets to fulfill their financing needs at competitive prices. Meanwhile, the initiatives to establish these by some governments in most West African countries and Southern African countries still remain in its infancy. In some West African countries, foreign exchange forwards exist with moderate liquidity and maturities extending up to 3-6 months. In 2008, a futures market based on treasury bonds was opened in Morocco. This is the first attempt to broaden the offering on the Casablanca Stock Exchange. While in Botswana, transactions concerning derivatives activity simply consist of over-thecounter foreign exchange forwards and currency swaps. However, both forwards and currency swaps markets are liquid, with terms up to 3-months and 6-months, respectively (Allen, Otchere, Lemma \& Senbet, 2011).

\section{Development and economic changes in Africa}

Sustainable development recognizes not only growth, but inclusive growth. It also includes environmentally sound plans to reduce poverty and build 
shared prosperity for today's population, which will continue to meet the needs of future generations (World Bank, 2001). This can work well if the plan is proficiently organized with enough financial resources and is carefully planned to deliver both immediate and long-term benefits for people, planet, and prosperity.

Meanwhile, development and growth have taken another shape in Africa. It was reported by the African Development bank (ADB, 2014) that, in 2013, Africa continued to demonstrate resilience in the face of a slow recovery in the global economy, although with broad variations across countries and regions. Growth in sub-Saharan Africa was 5\%, and excluding South Africa which was about 6\%. West Africa registered the highest rates of growth, about $7 \%$ (the same level as recorded in 2012), followed closely by East Africa with about $6 \%$, about $2 \%$ age points above those of 2012 . Central Africa grew at about $4 \%$ (compared to $6 \%$ in 2012) with the eruption of armed conflict in the Central African Republic reducing growth prospects for the sub-region in the near term. North Africa grew by $1.9 \%$, a decline of approximately $8 \%$ age points compared with 2012. In Southern Africa, growth averaged 3.0\%, indicating little change from 2012. Among major oil exporters, growth was highest for Angola, Gabon and Nigeria, at $5 \%$ or above. The investmentdriven economies, that are countries transitioning toward manufacturing and services as drivers of the economy, grew at between $3 \%$ to $7 \%$. Africa's average inflation fell by $2 \%$ age points to $6.7 \%$ in 2013 , compared to $2 \%$ in the US and the EU, and to a global average of $6 \%$. Overall, countries maintained a cautious fiscal stance. The average fiscal deficit as a percent of GDP rose to $3.9 \%$ in 2013 from $2.9 \%$ in 2012 . The current account deficit increased to $2.5 \%$ of GDP in 2013 from 1.5\% in 2012. Net oil-exporting countries saw their current account surplus as a percent age of GDP fall from 2.3\% in 2012 to $0.8 \%$ in 2013 , while the current account deficit was $8 \%$ of GDP for oil importers, compared to $7.6 \%$ in 2012 . Africa's growth is projected to be about $4.8 \%$ in 2014 and $5.7 \%$ in 2015 (ADB, 2014).

Also, in the area of technological development that is capable of accelerating economic development and growth in Africa, is the impressive rise in the adoption of mobile telephony in the continent. This has allowed innovative solutions to emerge, ranging from cashless payments to realtime price information, and these have contributed to the economic growth and well-being of African dwellers by allowing them to make better economic decisions. Also, in the area of digital education, much progress has been made. The major improvement in this line is the ability to boost people's productivity, the ability to innovate, and the contribution to the transformation of the economy (Kayizzi-Mugerwa, 2014). 


\section{Financial innovation and development/growth}

Financial innovation and financial system reforms are part of the solution to rapidly scaling capital for sustainable development. We can reason that such interventions can complement action in the real economy and deployment of public capital. The modern economy cannot exist without the efficient intermediations in the financial systems. The financial system is regarded as one of the most important creations of the modern society and it is described as an integrated part of the economic system. Financial innovation raises the efficiency of financial intermediation through an increased variety of financial products and services, resulting in improved matching of the needs of individual savers with those of firms raising funds for expanding future production. By this way, it systematically contributes to capital accumulation hence leading to economic growth (Chou, 2007). It has been documented that financial innovation helps to correct some kind of market inefficiency or imperfection. If markets are incomplete then financial innovation can improve opportunities for risk sharing. If there are agency conflicts, then new types of security can improve the alignment of interests. Financial innovation can lower taxes and it can avoid the effects of regulations in the financial market (Tufano, 2003). Financial innovation is good for economic growth based on the fact that such innovations will improve the allocation of capital. Due to the increasing sophistication and depth of financial markets resulting from financial innovations, it promotes economic growth by allocating capital where it can be most productive (Bernanke, 2007).

Financial innovation provides the mechanism to fund innovative technological projects when traditional sources of funds are unavailable due to high investment risk. Technological and economic progress resulting in a higher complexity of business processes and new types of risk, forces the financial system and financial markets to adapt to the changes and to be modernized according to the new requirements of the business entities and the challenges of the modern world. This leads to the conclusion that without financial innovations, technological and economic development would slow down and the wealth of nations would be lower. At the same time, the application of financial innovations would be limited without the demand arising from technical progress (Blash, 2011).

Financial innovation can assist individuals and firms to smooth expenditures in the case of temporary shortfalls in income. It may also lead to too much spending if they become over-confident. Financial innovation can increase economic uncertainties in different directions. If innovation comes with different changes in the financial system, it would have different effects on volatility. The different economic disturbances changes over time, the impact of augmenting or damping certain kinds of shocks will matter more or 
less in certain periods. A single type of innovation can affect households and firms differently, so one needs to aggregate the various responses (Elmendorf, 2008). A number of different forms of financial innovations can have different effects on the money demand hence economic growth (Dunne \& Kasekende, 2016). New products such as ATMs/ debit cards, and quasi-money such as financial instruments, could potentially improve efficiency and reduce transaction costs, in as much as, cash that would have been carried in wallets is replaced by these innovations. This could lead to a decline in demand for cash. A reduction in demand for money for transaction motives could deter economic growth and output. Also, individuals move away from more liquid assets to less liquid assets. This results in a demand for less money. On the other hand, financial innovations could potentially lead to an increase in money demand if payments systems improve but individuals demand more liquid assets. For example, where individuals demand electronic money and cash through the use of mobile phone technology but do not necessarily move away from more liquid assets to less liquid assets, this action may as well increase the transaction motives thereby increasing demand for goods and services in the economy, while at the same time improving economic growth. Financial innovation is good for the economy if it enables an economically productive use of money that would not otherwise occur. It is very clear that financial innovations may not necessarily add value to an economy. This can be the case when information asymmetries are present. This can happen if information asymmetries present particular contingencies that are not contractible, having complete markets is infeasible. It may also occur when contingencies are not verifiable, and/or too costly to verify. Introducing a financial innovation might not generate a good outcome or much motivation. Financial innovations might be intended to fool market participants. Financial innovations would then tend to worsen the allocation of capital (Johnson \& Kwak, 2009; Boot \& Marinc, 2010).

\section{EMPIRICAL REVIEW}

\section{Finance, competition and growth/development}

Early attempts to explain a finance-growth nexus can be found in Bagehot (1873), Schumpeter (1912), Gurley and Shaw (1955), Goldsmith (1969), and McKinnon (1973). Financial systems can affect savings-investment decisions and growth through acquiring and processing information about possible investment projects and entrenching constructive corporate governance; trading, diversification, and management of risk; mobilizing and pooling of savings, and facilitating the exchange of goods and services (Levine, 2005). 
These functions help to offset market imperfections, by lowering information and transaction costs, they help in fostering economic growth through more competitive and efficient allocation of financial resources (Khan \& Senhadji, 2000; Ajisafe \& Ajide, 2014; Ajide \& Aderemi, 2015). Furthermore, a number of studies have empirically proved that the financial market promotes growth (Spears, 1991; Thornton, 1995; Levine \& Zervos, 1998; Rousseau \& Wachtel, 2000; Calderon \& Liu ,2003; Caporale, Howells \& Soliman, 2004; Ajide, 2012). Other studies have also investigated the effect of competition on growth (Bikker \& Groeneveld, 2000; Bikker \& Haaf, 2002; Demirgüç-Kunt, Laeven \& Levine, 2003; Greenberg \& Simbanegavi, 2009; Schaeck \& Clhak, 2010; Ajide $\&$ Aderemi, 2015). They hinted that the industry intermediates large portions of capital flows and household savings in developing economies; which is based on the fact that the industry constitutes the primary source of business finance in developing countries. Healthy and effective banking competition is necessary because the absence of this condition can lead to a potential break-down in the financial system which can yield contagious effects to all other sectors of the economy (Ajide \& Soyoye, 2015).

The work of Maudos and Guevara (2006) examined the effect of financial development and banking competition on economic growth using both structural measures of competition (that is, market concentration) and measures based on the new empirical industrial organization perspective (Panzar and Rosse's test and the Lerner index). The study used the period 1993-2003 for a sample of 53 sectors in 21 countries and indicated that financial development and the exercise of bank market power promoted economic growth. This result is consistent with the literature on relationship lending which argues that banking competition can have a negative effect on the availability of finance for companies that are informationally more opaque. The results cast doubt on the use of market concentration measures as indicators of competition.

Claessens and Laeven (2005) using an indicator of market power based on the theory of industrial organization (i.e the $\mathrm{H}$ statistic of Panzar and Rosse) analyze the effect of banking competition on economic growth. Their results show that industries most dependent on bank financing grow faster in the countries with stiffer banking competition, so they reject the hypothesis that market power can favor access to finance. In addition, Claessens and Laeven (2003) in their study also relate a competition measure to industrial growth for 29 banking systems using the model developed by Rajan and Zingales (1998) which assesses the relationship between financial development and growth using sectoral growth data for a large sample of countries. They found that the effects of competition on access to financing (and growth) can depend on the level of development of the financial system. Specifically, in countries 
with less developed financial systems, financially dependent industries grow faster when the financial system is less competitive, while in more developed financial systems, more competition is associated with higher growth.

Bayraktar and Wang (2006) perceived that banking sector openness may directly affect growth by improving the access to financial services and indirectly by improving the efficiency of financial intermediaries, both of which reduce the cost of financing, and in turn, stimulate capital accumulation and economic growth. These direct and indirect links were confirmed using a more advanced econometric technique (GMM dynamic panel estimators) which linked financial market development with investment and provided support for countries planning to open their banking sector for international competition.

Soedarmono (2010) investigates the link between bank competition and economic development from a sample of Asian countries over the period 1999-2007. He states that, in general, although banking market power has a U-shaped relationship with economic growth, banking market power tends to improve economic growth. However, the positive impact of banking market power on economic growth only occurs in the agricultural sector, but not in the industrial sector. It is also shown that higher banking market power in countries with greater economic freedom erodes overall economic growth and industrial growth. On the contrary, there is no significant relationship between banking market power and agricultural growth in countries with greater economic freedom. He, therefore, concludes that when economic freedom increases and financial service investments come into a country, any policy to boost banking competition becomes necessary. In this case, the industrial sector is more important than the agricultural sector.

Asante, Agyapong and Adam (2011) empirically investigate the relationship between bank competition, stock market and economic growth in Ghana using time series data for the period 1992 to 2009, and the number of registered banks and trend as a proxy for bank competition. The short and long run relationships were established within the frameworks of Granger causality and the Autoregressive Distributed Lag (ARDL)/ Dynamic Ordinary Least Square (OLS) approach respectively. It was found that bank competition and stock market development granger caused economic growth in Ghana. Also, in the long run, banking competition is good for economic growth. However, there is a disproportionate response of economic growth to stock market development. 


\section{Financial innovation and growth/ development}

Ample studies have been conducted on financial system-growth nexus with mixed results. However, few of these studies pay attention to the issue concerning financial innovation. By seeking to answer the question "Is financial innovation necessary for sustaining economic growth?" Laeven, Levine and Michalopoulos (2015) built a Schumpeterian model in which entrepreneurs earn profits by inventing better goods and profit-maximizing financiers arise to screen entrepreneurs. The model has two novel features. First, financiers engage in the costly but potentially profitable process of innovation: they can invent better methods for screening entrepreneurs. Second, every screening process becomes less effective as technology advances. The model predicts that technological innovation and economic growth eventually stop unless financiers innovate. Empirical evidence is consistent with this dynamic, synergistic model of financial and technological innovation. A recent study by Dunne and Kasekende (2016) investigated the development of financial innovation and its impact on money demand in sub-Saharan Africa using panel data estimation techniques for 34 countries between 1980 and 2013. The results indicated that there was a negative relationship between financial innovation and money demand. This suggests that financial innovation plays a crucial role in explaining money demand in sub-Saharan Africa and can have important implications for future policy design. The factors influencing the adoption of financial innovation in Ghana's banking industry were carried out by Domeher, Frimpong and Appiah (2014). Surveys were conducted involving 405 clients of the six major banks in the country. Using logistical regression, the results showed that innovation attributes such as lack of complexity, compatibility and perceived usefulness provided by financial innovation, increase the likelihood of e-banking adoption. Anthony and Aboagye (2014) examined the relationship between bank competition, financial innovations and economic growth in Ghana using quarterly data from 1990 to 2009. They employed the ARDL co-integration procedures. The results showed that, in the long run, bank competition is positively related to economic growth whilst financial innovation is negatively related to economic growth. In the short run, bank competition is negatively related to economic growth. By the same token, financial innovation is positively related to economic growth in the short run. In terms of causality, the results showed that, there is unidirectional Granger causality from bank competition to economic growth. However, there is bidirectional Granger causality between financial innovation and economic growth. More regulations toward a more competitive banking system with more innovative products tailored toward mobilization of savings and investment to growth induced sectors of the economy were encouraged. 
Norden, Buston and Wagner (2014) found that banks with larger gross positions in credit derivatives charge significantly lower corporate loan spreads, while banks net positions are not consistently related to loan pricing. They argued that this is consistent with banks passing on risk management benefits to corporate borrowers but not with alternative channels through which credit derivative use may affect loan pricing. They also found that the magnitude of the risk management effect remained unchanged during the crisis period. In addition, banks with larger gross positions in credit derivatives cut their lending by less than other banks during the crisis and have consistently lower loan charge-offs. Their study is suggestive of significant risk management benefits from financial innovations that persist under adverse conditions, that is, when they matter most.

Further investigation on the effect of financial development on innovation for 51 countries between 1993 and 2008 was carried out by Meierrieks (2014). Consistent with the expectations from Schumpeterian models of finance, entrepreneurship and economic growth it was found that higher levels of financial development coincide with stronger innovative activity. It was further stressed that financial intermediaries may indeed encourage investment in innovative entrepreneurial activity. Hao and Hunter (1997) examined the link between banking, financial system structure and economic growth, by constructing a cross-country regression model using data over the 1970-1988 periods. They extended the existing literature by explicitly examining the impact of measures of a country's financial deepness, in terms of second stage financial innovations, on a country's rate of economic growth. The results showed that financial development (e.g., as measured by the presence of an organized financial futures market-a second stage innovation) is positively correlated with enhanced economic growth.

\section{METHODOLOGY}

\section{Data and sources}

The new database of financial development and structure across countries and over time in the World Bank development indicator has been used to source data to carry out this study. This database is unique in that it unites a wide variety of indicators that measure the size, activity and efficiency of financial intermediaries and markets. It improves on previous efforts by presenting data on the size and activity of bank and non-bank financial institutions. The study covered the period 2000-2013 utilizing secondary data sourced from this database in the World Bank financial Development Indicators. The study used eight West African countries; Benin, Ghana, Niger, 
Nigeria, Senegal, Mali, Sierra-Leone and Burkina Faso. All the data used were drawn from the Word Bank Development Indicators (2015). Table 2 provides a summary of data source and the period involved.

Table 2. Summary of data source and the period

\begin{tabular}{|c|c|c|}
\hline Data description & Period & Sources \\
\hline Adjusted net saving & $2000-2013$ & World bank development indicator (2015) \\
\hline GDP per capita & $2000-2013$ & World bank development indicator(2015) \\
\hline Bank return on Assets(after tax) & $2000-2013$ & $\begin{array}{l}\text { Financial development and structure } \\
\text { (World bank Indicators, 2015) }\end{array}$ \\
\hline Boone Indicator & $2000-2013$ & $\begin{array}{l}\text { Financial development and structure } \\
\text { (World bank Indicators, 2015) }\end{array}$ \\
\hline Bank concentration index (\%) & $2000-2013$ & $\begin{array}{l}\text { Financial development and structure } \\
\text { (World bank Indicators, 2015) }\end{array}$ \\
\hline $\begin{array}{l}\text { Narrow and Broad Money (M1 } \\
\text { and } \mathrm{M} 3 \text { ) }\end{array}$ & $2000-2013$ & World bank development indicator (2015) \\
\hline
\end{tabular}

\section{Empirical model}

An investigation into the relationship between financial innovation and development/growth can be examined using the simplest endogenous growth model normally called $A K$ model (Pagano, 1993); where $K$ is capital stock and $A$ is the level of technology (which is taken as given in the economy). We can say that aggregate savings transform into capital stock. The capital stock can be generated from the banking sector's activities which are affected by competition and financial innovation in the financial intermediation in the industry. This arrangement can be modeled using the $A K$ model to empirically show: firstly, the effects of bank competition and financial innovation on economic growth and secondly, to examine the effect of bank competition and financial innovation on sustainable development. To show the effect of bank competition and financial innovation on growth, we specified the model as:

In econometric term, it can be specified as:

$$
L G D P P=f(B R, B C, C P, F I)
$$

Also, to show the effect of bank competition and financial innovation on sustainable development, we specified the model as:

$$
L G D P P_{i t}=\beta_{0_{i t}}+\beta_{1} B R_{i t}+\beta_{2} B C_{i t}+\beta_{3} C P_{i t}+\beta_{4} F I_{i t}+\varepsilon_{i t}
$$

In econometric term, it can be specified as:

$$
S D_{i t}=\beta_{0 i t}+\beta_{1} G D P P_{i t}+\beta_{2} B R_{i t}+\beta_{3} B C_{i t}+\beta_{4} F I_{i t}+\varepsilon_{i t}
$$


Where $S D$ is Sustainable Development, $L G D P P$ is economic growth, $B C$ is Bank Competition, $\boldsymbol{B} \boldsymbol{R}$ is Bank Return, $\boldsymbol{F}$ is financial innovations, and $\boldsymbol{C P}$ is Banking Sector development. Also, GDPP is GDP per capita and is used as a proxy for income of individual in the economy

\section{Dependent variables}

Sustainable Development (SD) serves as one of dependent variables in the model built for the study. We have used Adjusted Net Savings as a measure of sustainable development (Gnegne, 2009; Blanchet, Le cacheux \& Marcus, 2009; Pardl, Arifin, Salleh, \& Nawi, 2015). Adjusted Net Saving (ANS), as a \%age of Gross National Income (GNI), is derived from the standard national accounting measure of gross saving by making four adjustments: (i) consumption of fixed capital is deducted to obtain net national saving; (ii) current public expenditure on education is added to account for investment in human capital; (iii) estimates of the depletion of a variety of natural resources are deducted to reflect the decline in asset values associated with extraction and depletion; (iv) deductions are made for damages from carbon dioxide and particulate emissions. The indicator is then computed by dividing ANS by GNI. The second dependent variable is LGDPP is defined as economic growth proxy by Log of Real Per capita GDP.

\section{Independent variables}

\section{Competition}

$B C$ is defined as Bank Competition. The study used two measures of bank competition (Bank concentration and Boone Indicator). Bank concentration is used as a measure of market dominating power within an industry or among companies. Bank concentration index of the highest three (CR3) total deposits is used. We also employed the Boone indicator proposed by Boone (2008). The Boone indicator (BI) reflects more than $80 \%$ of the information contained in other measures of competition such as the $\mathrm{H}$-statistic and other variables like government ownership of banks and the Financial Freedom index (Schaek \& Cihák, 2010).

\section{Bank Return}

$\boldsymbol{B} \boldsymbol{R}$ is defined as Bank Return. We employed this ratio as a proxy for banking sector efficiency; it is measured as bank returns as a \%age of Total Assets. We have used this variable to account for issues concerning banks' profitability and efficiency of the banking sector potentially not captured by our two measures of competition (that is, Concentration ratio and Boone indicator). 


\section{Financial innovation variables}

Among the functions of financial innovation are; the effective movement of funds at the appropriate time; the pooling of funds; extracting information to support decision-making; and facilitating the sale and purchase of goods and services through a payment system. However, we recognize that different forms of financial innovations can have different effects on growth/development. For instance, ATMs/debit cards and quasi-money among others, could potentially improve intermediation efficiency and reduce transaction costs, in as much as cash that would have been carried in wallets is replaced by these innovations. This could lead to a decline in demand for cash. A reduction in demand for money for transaction motives could deter economic growth and output. Also, individuals could move away from more liquid assets to less liquid assets. This results in demand for less money. Therefore, to measure financial innovations $(\boldsymbol{F I})$, we employed the ratio of $M_{3}$ to $M_{1}$ (Dunne \& Kasekende, 2016; Hye, 2009; Mannah- Blankson \& Belyne, 2004). We also employed growth of the ratio of bank credit to the private sector to GDP (growth of $\mathbf{C P}$ ). This is because the revolution of technological innovations spearheaded by the application of information and communication technology can strengthen the efficiency of the banks to mobilize savings and allocate funds to productive areas (Anthony\& Aboagye, 2014).

\section{Control variables}

We employed $\boldsymbol{C P}$ and GDP per capita as control variables. $\boldsymbol{C P}$ is defined as Banking Sector development proxy by Credit to private sector as a \%age of GDP. Also, GDP per capita is used as a proxy for income of individual in the economy. We expect that as individual income increases sustainable development is enhanced.

\section{Method of analysis}

The panel data analysis has been carried out to find out the effect of bank competition and financial innovation on growth/sustainable development. The panel character of data allows for the use of panel methodology. The panel data estimations are considered the most efficient analytical methods in handling econometric data of this kind. The panel data model is a powerful and strong research instrument. The combined panel data matrix set consists of a time series for each cross sectional member in the data set, and of variety of estimation methods. The main purpose of using panel data is because it provides a more efficient estimation of parameter by considering a broader source of variation, it outsources more information to the researcher and it 
allows the study of dynamic behavior parameters. Precisely, we use pooled OLS, fixed effect and random effect estimation; appropriate estimations are determined using the Hausman test.

\section{RESULTS AND DISCUSSION}

Table 3 and 4 report the correlation matrix and descriptive statistic of the variables adopted for the study. It can be seen that $M C$ has a negative relationship with LGDPP. We observe a similar characteristic between credit to private sector (CP) and BR and LGDPP, BI and BR. There is a positive relationship between CP and LGDPP. The correlation between CP and LGDPP is commendable as most studies have proved that financial development has a positive correlation with economic growth (Levine, 2005; Akinlo \& Olufisayo, 2009).

The descriptive statistic shows that the growth rate is $6.2 \%$ on average with maximum of $6.9 \%$ and minimum of $5.5 \%$. This reflects the significant government reforms in Africa. The development prospects for African countries remain promising, with real growth forecasted by the IMF to be above $4 \%$ in 2015 . The level of volatility is $0.4 \%$. The Boone indicator shows a fiercer competitive condition in the banking industry with an average figure of $-0.11 \%$, with a maximum value of $0.061 \%$ and minimum value of $-0.69 \%$. This shows the dynamic movement of the competitive environment in the West African banking industry. Standard deviation shows the level of volatility is $0.118 \%$. Meanwhile, banking sectors are typically concentrated as the average is about $77 \%$ which may lead to inefficiencies in financial intermediation in the long run. According to the World Bank's Financial Inclusion Database, only $24 \%$ of adults in SSA had a bank account in 2011. Consequently, access to finance in sub-Saharan Africa, though expanding, remains among the lowest in the world and one of the key obstacles to the activity and growth of enterprises. The ongoing structural changes, such as the emergence of mobile banking, are beginning to strengthen competition, to deepen sub-Saharan financial markets and improve access to finance. The soundness and efficiency of the industry is depicted by the variable BR with a maximum value of $18.74 \%$ and minimum value of $-18.02 \%$. On average the level of profitability is $2.72 \%$. The adjusted savings is 0.45 on average, with a volatility level of 8.30 . 
Table 3. Descriptive statistics

\begin{tabular}{llllllll}
\hline & $\begin{array}{l}\text { Adj. Net } \\
\text { Sav. }\end{array}$ & LGDPP & BI & BR & MC & $\begin{array}{l}\text { Growth } \\
\text { of CP }\end{array}$ & M3/M1 \\
\hline Mean & -0.45186 & 6.186846 & -0.11508 & 2.720481 & 76.61770 & 2.50198 & 0.97374 \\
Median & -0.12117 & 6.186468 & -0.07662 & 2.096897 & 77.75488 & 2.62516 & 1.0000 \\
Maximum & 19.0525 & 6.962089 & 0.06108 & 18.7446 & 100.000 & 3.58377 & 7.99893 \\
Minimum & -20.3889 & 5.509877 & -0.69448 & -18.0628 & 23.75945 & 0.34661 & -10.4042 \\
Std Dev. & 8.30653 & 0.379302 & 0.11861 & 3.478881 & 17.02623 & 0.63106 & 1.30141 \\
Observ. & 112 & 112 & 112 & 112 & 112 & 112 & 112 \\
\hline
\end{tabular}

Table 4. Correlation analysis

\begin{tabular}{llllllll}
\hline & $\begin{array}{l}\text { Adj. Net } \\
\text { Sav. }\end{array}$ & LGDPP & BI & BR & MC & $\begin{array}{l}\text { Growth } \\
\text { of CP }\end{array}$ & M3/M1 \\
\hline $\begin{array}{l}\text { Adj. Net } \\
\text { saving }\end{array}$ & 1.0000 & & & & & & \\
LGDPP & 0.324472 & 1.0000 & & & & & \\
BI & 0.183623 & 0.276233 & 1.0000 & & & & \\
BR & 0.066928 & -0.27623 & -0.39609 & 1.0000 & & & \\
BC & 0.131093 & -0.40578 & -0.101985 & 0.277284 & 1.0000 & & \\
Growth of & 0.363669 & 0.647190 & 0.629801 & -0.54433 & -0.340336 & 1.0000 & \\
CP & & & & & & & \\
M3/M1 & 0.000384 & 0.025937 & -0.013341 & 0.049855 & 0.005431 & -0.04043 & 1.0000 \\
\hline
\end{tabular}

Our estimations are presented in Table 5 and Table 6. Table 5 shows the effect of bank competition and financial innovation on economic growth while Table 6 shows the effect of bank competition and financial innovation on sustainable development. As depicted in Table 4, the Hausman test shows that random effect is the most appropriate estimate for the model of bank competition, financial innovation and growth. The bank return has a negative relationship with growth, while the two measures of competition (market concentration and Boone indicator) reflect a positive relationship with growth. This means that effective competition in the banking industry would increase the level of economic growth. The same applies to innovation in industry. As the financial innovation variable shows, a one-\% increase in financial innovation would accelerate the level of growth in West Africa. The variable on financial development (credit to private sector) reflects a positive relationship with economic growth. We are not surprised with this result because various studies have proved the relationship (e.g., Levine, 2005; Akinlo \& Olufisayo, 2009). A critical look at the results would confirm that financial innovation is not significant, while other variables are significant. A good reason for this is that the majority of the financial transactions in West African countries are still based on a conventional banking system; the 
banks are only innovating old systems (such as the use of cheques and cash deposits) and most of these changes are only reducing the long queue in the banking hall. The F-statistic of 9.866984 reflects the overall significance of the model.

As aforementioned, Table 6 shows the effect of bank competition and financial innovation on sustainable development. The Hausman test shows that the appropriate estimation is the fixed effect. In the fixed effect, it can be envisaged that income is important in the model. It reflects a positive relationship with development, as higher income means higher development. The two measures of competition exhibit a positive relationship with development. Effective competition would ginger up development and growth. This result is consistent with the previous studies (Maudos \& Guevara, 2006; Soedarmono, 2010). Also, we have used two measures of financial innovations. They are based on the idea that different forms of financial innovations can have different effects on growth/development. The growth of is negative. A major reason for this relationship is that ATMs/ debit cards and quasi-money could potentially improve efficiency and reduce transaction costs, in as much as cash transactions are replaced by financial innovations. This could lead to a decline in demand for cash. A reduction in demand for money would not make a consumer become an active spender in buying firms' products and services. It contrasts demand for transaction motives which could deter economic growth and output. Also, individuals move away from more liquid assets to less liquid assets. This results in a demand for lesser cash for transactions. The second measure exerts a positive relationship on development. The growth of credit to private sector (cp) has a positive relationship with development.

Table 5. Effect of bank competition and financial innovation on economic growth

\begin{tabular}{llll}
\hline & Pooled OLS & Fixed effect & Random effect \\
\hline Bank Return(BR) & 0.012168 & $-0.014603^{*}$ & $-0.014063^{*}$ \\
& $(0.009032)$ & $(0.004279)$ & $(0.004266)$ \\
Boone Indicator(BI) & -0.316444 & $0.474607^{* *}$ & $0.463716^{* *}$ \\
& $(0.273961)$ & $(0.183404)$ & $(0.463716)$ \\
Market consent(MC) & $-0.004997^{*}$ & $0.002183^{* *}$ & $0.002029^{* *}$ \\
& $(0.001655)$ & $(0.000828)$ & $(0.000825)$ \\
Credit to private & $0.039989^{*}$ & $0.008217^{*}$ & $0.008978^{*}$ \\
sectors(CP) & $(0.005385)$ & $(0.003108)$ & $(0.003089)$ \\
& 0.015084 & 0.008175 & 0.008221 \\
Fin. Inn(M3/M1) & $(0.020209)$ & $(0.008080)$ & $(0.008079)$ \\
& & & \\
\hline
\end{tabular}




\begin{tabular}{llll}
\hline & Pooled OLS & Fixed effect & Random effect \\
\hline Constant & $5.917231^{*}$ & $5.989242^{*}$ & $5.987440^{*}$ \\
& $(0.181252)$ & $(0.084311)$ & $(0.138834)$ \\
R-Square & 0.4922 & 0.925169 & 0.317604 \\
Adj.R-Square & 0.468284 & 0.916098 & 0.285415 \\
F-stat & 20.55161 & 101.998 & 9.866984 \\
Prob(F-Stat) & 0.000000 & 0.00000 & 0.000000 \\
\hline Huasman Test: & & & \\
\hline Chi-squ. & & 6.84975 & \\
Prob(chi-sq) & & 0.2321 & \\
\hline
\end{tabular}

Dependent variable: Log of GDPP

${ }^{*} 1 \%$ sign., $* * 5 \%$ sign., $* * * 10 \%$ sign. Figures in ( ) are standard error.

Table 6. Effect of bank competition and financial innovation on sustainable development

\begin{tabular}{llll}
\hline & Pooled OLS & Fixed effect & Random effect \\
\hline Income(GDPP) & $4.231050^{* * *}$ & $21.50214^{*}$ & $9.88571^{*}$ \\
& $(2.485627)$ & $(5.778365)$ & $(3.236538)$ \\
Boone Indicator(BI) & -4.382143 & 10.4489 & 6.387798 \\
& $(7.548415)$ & $(10.25161)$ & $(7.982581)$ \\
Bank Return(BR) & $0.739207^{*}$ & $0.602380^{* *}$ & $0.549895^{* *}$ \\
& $(0.235875)$ & $(0.247806)$ & $(0.223292)$ \\
Market consent(MC) & $0.148563^{*}$ & $0.158686^{*}$ & $0.180858^{*}$ \\
& $(0.044303)$ & $(0.047159)$ & $(0.042000)$ \\
Fin. Inn(Growth of CP) & $7.241972^{*}$ & 2.629892 & $4.089911^{*}$ \\
Fin. Inn(M3/M1) & $(1.936519)$ & $(2.376480)$ & $(2.021383)$ \\
& -0.001958 & -0.174483 & -0.068722 \\
Constant & $(0.518766)$ & $(0.444683)$ & $(0.442477)$ \\
& $-58.64399^{*}$ & $-152.4868^{*}$ & $-86.39698^{*}$ \\
R-Square & $(14.61031)$ & $(33.60769)$ & $(18.76724)$ \\
Adj.R-Square & 0.311924 & 0.536488 & 0.290436 \\
F-stat & 0.272605 & 0.475002 & 0.249889 \\
Prob(F-Stat) & 7.933228 & 8.725342 & 7.163023 \\
\hline Huasman Test: & 0.000000 & 0.00000 & 0.000002 \\
\hline Chi-squ. & & & \\
Prob(chi-sq) & & 0.0077 & \\
\hline
\end{tabular}

Dependent variable: Adjusted Net savings(SD)

${ }^{*} 1 \%$ sign., ${ }^{* *} \%$ sign., ${ }^{* * *} 10 \%$ sign. Figures in ( ) are standard error 
This agrees with the submission of Anthony and Aboagye (2014) who confirm that financial innovation is positively related to economic growth. This means that, the revolution of technological innovations spread the application of information and communication technology which have strengthened the efficiency of the banks to mobilize savings and allocate them to productive sectors of the economy. From the view of Schumpeter (1934), innovations may lead to competitive advantage that can be exploited by innovative firms. This view supports a substantial body of scholars who have suggested that the relationship between a firm's level of innovation and performance should be positive. This would substantially improve the level of development by improving the level of employment and providing quality products to consumers (Christensen \& Bower, 1996; McWilliams \& Siegel, 2000; Schumpeter, 1934; Zahra \& Covin, 1995).

\section{CONCLUSION}

Financial innovation has brought a new trend to the modern financial system and its importance has been widely recognized. The importance of new products and services in the financial system has been well highlighted (Miller, 1986; Merton, 1992). Innovations are not only critical for firms in the financial services industry, but also affect other companies by enabling them to raise huge capital at a lower cost than they could otherwise. Our study investigated the effect of bank competition and financial innovation on sustainable development/growth in selected West African countries. We used two measures of competition (market concentration and Boone indicator), two measures of financial innovation (growth of credit to private sector as a \% age of GDP and ratio of $M_{3}$ to $M_{1}$ ) and we regressed them on a growth indicator as well as a sustainable development indicator with other control variables using panel data. Our results confirmed that an increase in banking efficiency driven by competition and financial innovation would improve economic growth and development. However, the growth or development effect of financial innovation is sensitive to the choice of proxy. While the two proxies of competition were significant, the financial innovations were not significant; one displayed a negative, while the other exhibited a positive relationship with development. These results revealed the differential effects of different financial innovations adopted in the financial system. A reduction in demand for money caused by financial innovations could deter economic growth and development. This implies that individuals would move away from more liquid assets to less liquid assets, which in turn discourage consumption. On the other hand, financial innovations could potentially lead to an increase in money demand if payment systems improve and individuals demand more 
liquid assets, hence, consumption is encouraged. By implication, production would increase, leading to an increase in growth and development. Our findings here reaffirm the submission of Adu, Marbuah, and Mensah (2013) who state that, whether financial development is good or bad for growth depends on the indicator used to proxy for financial development. We therefore propose that policies that can drive competition and efficiency in the banking industry, as well as a growth-enhanced innovation, should be introduced to ensure effective functioning of the financial system.

\section{Acknowledgement}

The author would like to thank the guest editor, Katarzyna Prędkiewicz, and the three anonymous referees for their valuable comments and suggestions to improve the quality of this paper.

\section{References}

Abor, J. (2005).Technological innovations and banking in Ghana: An Evaluation of customers' perceptions. African Journal Online. Retrieved from http:// www.ajol.info/index.php/ifep/cart/view/23668/20166

Adua,G., Marbuah, G., \& Mensah, J. T. (2013). Financial development and economic growth in Ghana: Does the measure of financial development matter? Review of Development Finance, 3,192-203.

African Development Bank (ADB, 2014). African economic outlook. Retrieved from http://www.afdb.org/en/countries/

Ajide, F. M. (2012). The effects of stock market activities on the performance of economic indicators in Nigeria: An empirical investigation (1985-2010). Lagos Journal of Entreprneurship and Technology (LJET),1(6),73-83.

Ajide, F. M., \& Aderemi, A. A. (2015). Market power of Nigerian deposit money market: Evidence from Bresnahan-Lau's approach. American Journal of Economics, 5(1), 21-28.

Ajide, F.M., \& Ajileye, J. O. (2015). Market concentration and profitability in Nigerian banking industry: Evidence from error correction modeling. International Journal of Economics, Commerce and Management, 3(1), 1-8.

Ajide, F. M., \& Soyoye, O. O. (2015). Concentration and competition in Nigerian banking industry: A review. ICAN Journal of Accounting and Finance, 5(1), 1-8.

Ajisafe, R.A., \& Ajide, F. M. (2014). Bank competition and economic growth: Empirical evidence from Nigeria (1986-2012). Journal of Emerging Trends in Economics and Management Sciences, 5(5),419-425.

Ajisafe, R.A., \& Akinlo, A.E. (2014). Competition and efficiency of commercial banks: Empirical evidence from Nigeria. American Journal of Economics, 4(1), 18-22. 
Akinlo, A. E., \& Olufisayo, O. (2009). Stock market development and economic growth: Evidence from seven Sub-Sahara African countries. Journal of Economics and Business, 61, 162-171.

Allen, F. Otchere, I., Lemma,W., \& Senbet, L. W. (2011). African financial systems: A review. Review of Development Finance, 1(2),79-113.

Anthony, A. I., \& Aboagye, Q.Q. (2014). Bank competition, financial innovations and economic growth in Ghana. African Journal of Economic and Management Studies, 5(1), 30-51.

Asante, S., Agyapong, D., \& Adam, M.A. (2011). Bank competition, stock market and economic growth in Ghana. International Journal of business Administration, 2(4), 33-41.

Arrau, P., \& Gregorio, J. (1991). Financial innovation and money demand. International Economics Department, The World Bank working paper, WPS 585.

Bagehot, W. (1873). Lombard street: A description of the money market. London, England: John Murray.

Bernanke, B. (2007). Regulation and financial innovation, speech to the Federal Reserve Bank of Atlanta's 2007 Financial Markets Conference. Sea Island, Georgia, May 15, 2007. Retrieved from http://www.federalreserve.gov/ newsevents/speech/bernanke20070515a.htm

Bayraktar, N., \& Wang, Y. (2006). Banking sector openness and economic growth. World Bank Policy Research Working Paper 4019.

Bikker, J., \& Groeneveld, J. (2000). Competition and concentration in the EU banking industry. Kredit und Kapital, 33, 62-98.

Bikker, J., \& Haaf, K. (2002). Competition, concentration and their relationship: An empirical analysis of the banking industry. Journal of Banking \& Finance, 26, 2191-2214.

Blanchet, D., Le Cacheux, J., \& Marcus, V. (2009). Adjusted net savings and other approaches to sustainability: Some theoretical background. Retrieved from www.insee.fr/en/publicationset-services/does_doc_ travail/G2009-10.pdf

Boone, J. (2008). A new way to measure competition. Economic Journal, 118, $1245-1261$.

Boot, A. W. A., \& Marinč, M. (2010). Financial innovation: Economic growth versus instability in bank-based versus financial market driven economies. Retrieved from www.researchgate.net/publication/228953198_financial _innovation_economic_growth_v

Calderon, C., \& Liu, L. (2003). The direction of casualty between financial development and economic growth. Journal of Development Economics, 72, 321-334.

Caporale, G. M., Howells, P., \& Soliman, A. M. (2004). Endogenous growth models and stock market development: Evidence from four countries. Review of Development Economics, 9(2), 166-176. 
Claessens, S., \& Laeven, L. (2005). Financial dependence, banking sector competition, and economic growth. Journal of European Economic Association, 3(1), 179-207.

Chou, Y. K. (2007). Modeling financial innovation and economic growth: Why the financial sector matters to the real economy. The Journal of Economic Education, 38(1), 78-90.

Costanzo, L. A., Keasey, K., \& Short, H. (2003). A strategic approach to the study of innovation in the financial services industry: The case of telephone banking. Journal of Marketing Management, 19(3/4), 259-281.

Demirgüç-Kunt, A., \& L. Klapper. (2012). Measuring financial inclusion: The global findex. World Bank Policy Research Working Paper Series 6025. World Bank, Washington, D.C.

Demirguc-Kunt, A., Laeven, L., \& Levine, R. (2003). Regulations, market structure, institutions, and the cost of financial intermediation. Journal of Money, Credit, and Banking, 36(3), 593-622.

Dunne, P. J., \& Kasekende, E. (2016). Financial innovation and money demand: Evidence from Sub-Saharan Africa. South Africa: Economic Research Southern Africa (ERSA).

Dasgupta, D. P. (2015). Financial innovation and the state: Lessons for 21st century climate finance from the 19th century railways Era. A special series discussing the economic dimensions of environmental issues ahead of the - COP 21 Climate change Conference held in Paris on 30 November-11 December 2015.

Econsultancy (2012). Crowdfunding in numbers: Stats. Retrieved from http:// econsultancy.com/blog/10074-crowdfunding-in-numbersstats

Elmendorf, D.W. (2008). Financial innovation and housing: Implications for monetary policy. A comment prepared for a Brookings Institution event on The Housing Crisis and Lessons for Monetary Policy. April,2008. The Brookings Institution.

Goldsmith, R.W. (1969). Financial structure and development. New Haven, CT: Yale University press.

Greenberg, J.B., \& Simbanegavi, W. (2009). Testing for competition in the South African banking Sector, Faculty of Commerce University of Cape Town. Retrieved from http://www.commerce.uct.ac.za/economics/ seminars $/ 2009 / 20091106 \% 20$ Simbanegavi $\% 20$ Measuring $\% 20$ competition\%20in\%20Banking\%20sector.pdf

Gnegne, Y. (2009). Adjusted net savings and welfare change. Ecological Economics, 68(4), 1127-1139.

Gurley, J.G., \& Shaw, E.S. (1955). Financial aspects of economic development. American Economic Review, 45, 515-538.

Hao, J., \& Hunter, W. C. (1997). A Test of the impact of financial innovation on economic growth, Managerial Finance, 23(11), 64-78.

Hye, Q., \& Adnan, M. (2009). Financial innovation and demand for money in Pakistan. Asian Economic Review 51(2), 219-228. 
Johnson, S., \& Kwak J. (2009). Finance: Before the next meltdown. DemocracyJournal.org, Fall, 19-24.

Kayizzi-Mugerwa, S. (2014). Knowledge and Innovation for Africa's Structural Transformation. Retrieved from http://www.afdb.org/en/blogs/afdbchampioning-inclusive-growth-across-africa/post/knowledge-andinnovation-for-africas-structural-transformation-13691/

Khan, M. S., \& Senhadji, A. S. (2000). Financial development and economic growth: An overview. IMF Working Paper WP/00/209. Washington: International Monetary Fund.

Laeven, L., Levine, R., \& Michalopoulos, S. (2015). Financial innovation and endogenous growth. Journal of Financial Intermediation, 24(1), 1-24.

Levine, R. (2005). Finance and growth: Theory and evidence. In P. Aghion \& S. Durlauf (Eds.), Handbook of Economic Growth, 1 (pp. 865-934). Amsterdam, Netherlands: Elsevier.

Levine, R., \& Zervos, S. (1998). Stocks markets, banks, and economic growth. American Economic Review, 88, 537-558.

Mazzucato, M. (2013). Financing innovation: Creative destruction vs. destructive creation. Industrial and Corporate Change, 22(4), 851-867.

Maudos, J., \& Guevara, J.F. (2006). Banking competition, financial dependence and economic growth. MPRA Paper No. 15254. Retrieved from http:// mpra.ub.uni-muenchen.de/15254/

McKinnon, R. I. (1973). Money and capital in economic development. Washington D.C.: Brookings Institution.

Mention, A. L. (2011). Innovation for financial services. Innovation Management. Retrieved from http://www.innovationmanagement. se/2011/09/13/innovation-for-financial-services

Merton, R. C.(1992). Financial innovation and economic performance. Journal of Applied Corporate Finance, 4, 12-22.

Melnick, R., \& Eran Y. (1994). Macroeconomic effects of financial innovation: The Case of Israel. Discussion Paper No. 94.05. Retrieved from http:// www.boi.org.il/en/Research/DiscussionPapers1/dp9405e.pdf

Meierrieks, D. (2014). Financial development and innovation: Is there evidence of a Schumpeterian finance-innovation nexus? Annals of Economics and Finance 15(2), 343-363.

Miller, M. H. (1986). Financial innovation: The last twenty years and the next. Journal of Financial and Quantitative Analysis, 21, 459-471.

Michalopoulos, S., Laeven, L., \& Levine, R. (2009). Financial innovation and endogenous growth. NBER working paper series. Working Paper 15356. Retrieved from http://www.nber.org/papers/w15356.

Motta, M. (2004). Competition Policy: Theory and Practice. Cambridge University Press, New York.

Nickell, S. (1996). Competition and corporate performance. Journal of Political Economy, 104, 724-746. 
Norden, L., Buston, C. S., \& Wagner, W. (2014). Financial innovation and bank behavior: Evidence from credit markets. Journal of Economic Dynamics and Control, 43, 130-145.

Thornton, J. (1995). Financial deepening and economic growth in developing countries. Economia Internazionale, 48, 423-30.

Tufano, P. (2003). Financial Innovation. In: G. Constantinides, M. Harris \& R. Stulz (Eds.), The Handbook of the Economics of Finance, Part 1 (pp. 307335). Amsterdam, Netherlands: Elsevier: Elsevier.

Pagano, M. (1993). Financial markets and growth. An overview. European Economic Review, 37, 613-622.

Pardl, F., Arifin Md. Salleh, A. M., \& Nawi, A. S. (2015). Determinants of sustainable development in Malaysia: A VECM approach of short-run and long-run relationships. American Journal of Economics, 5(2), 269277.

Rajan, R., \& Zingales, L. (1998). Financial dependence and growth. American Economic Review 88, 559-586.

Rousseau, P.L., \& Wachtel, P. (2000). Equity markets and growth: Cross-country evidence on timing and outcomes, 1980-1995. Journal of Banking and Finance, 24, 1993-1957.

Salas, O. (2009). The future of innovation: A leverage for sustainable development and social inclusion. Retrieved from http://thefutureofinnovation.org/contributions/view/598/the_future_of_innovation _a_leverage_for_sustainablt_development_and_social_inclusion

Simpasa A. M. (2013). Increased foreign bank presence, privatization and competition in the Zambian banking sector. Managerial Finance, 39(8), 787-808.

Soedarmono, W. (2010). Bank competition, institution and economic development: Evidence from Asia during 1999-2007. Economics Bulletin, 30(3), 2119-2133.

Schumpeter, J. (1934). The theory of economic development. Cambridge, Mass.: Harvard University Press. First published in German, 1912. Republished New York: Oxford University Press, 1961.

Schaeck, K., \& Cihák, M. (2010). Competition, efficiency, and soundness in banking: An industrial organization perspective. Discussion Paper No.2010-68S, Center for Economic Research, Tilburg University. Retrieved from https://pure.uvt.nl/portal/files/1246791/2010-20S.pdf

Spears, A. (1991). Financial development and economic growth: Causality tests. Atlantic Economic Journal, 19, 66.

Whish, R. (2005). Competition Law. New York: Oxford University Press.

World Bank (2001). What is sustainable development? Retrieved from http:// www.worldbank.org/depweb/english/sd.html 


\begin{abstract}
Polish)
Innowacje finansowe sq nieodzownym elementem współczesnego systemu finansowego. Badania zaprezentowane w artykule dotyczq znaczenia innowacji finansowych dla konkurencji bankowej oraz ich wpływu na zrównoważony rozwój w ośmiu krajach Afryki Zachodniej i zostały oparte na wskaźnikach rozwoju opracowanych przez Bank Światowy z lat 2000-2013. W badaniach jako zmienne objaśniane wykorzystano wskaźnik wzrostu jak i rozwoju, a wśród zmiennych objaśniajq̨cych znalazły się między innymi dwie zmienne opisujqce konkurencyjność, dwie zmiennie określajqce innowacje finansowe. Na podstawie analizy danych panelowych stwierdzono, że wzrost efektywności w systemie bankowym wywołany przez konkurencję i innowacje finansowe przyczynia się do wzrostu gospodarczego i rozwoju. W modelach dwie zmienne objaśniajqce w zakresie konkurencyjności okazały się statystycznie istotne, natomiast zmienne w zakresie innowacji finansowych nie były istotne - jedna wykazywała negatywny, podczas gdy druga pozytywny wpływ na wskaźniki rozwoju. Badania ujawniły zróżnicowane efekty innowacji finansowych zaadaptowanych w systemach finansowych, co oznacza, że efekt wzrostu wywołany przez innowacje finansowe jest wrażliwy na dobór zmiennej objaśniajqcej. Zmniejszenie popytu na pieniqqdz wywołane innowacjami finansowymi może spowolnić wzrost gospodarczy i rozwój. Wynika to z faktu, że osoby fizyczne mogq konwertować swoje aktywa z bardziej płynnych na mniej płynne. $Z$ drugiej strony innowacje finansowe mogq potencjalnie wpłynqć na wzrost popytu na pieniqdz jeżeli system płatności zostanie usprawniony i indywidualny popyt na bardziej płynne aktywa zostanie przeniesiony na sektor produkcyjny. W zwiqzku z tym stwierdza się, że w celu zapewnienia funkcjonowania efektywnego systemu finansowego polityka powinna pobudzać konkurencję i efektywność w systemie bankowym jak i innowacje finansowe.
\end{abstract}

Słowa kluczowe: innowacje finansowe, konkurencja, rozwój, Afryka.

\title{
Biographical note
}

Folorunsho M. Ajide, is a Lecturer in the Department of Economics, Faculty of Social and Management Sciences, Southwestern University, Nigeria. He is an alumnus of Lagos State Polytechnic, Lagos (Dipl., Accountancy), University of Ilorin, Ilorin (B.Sc. Economics) and Obafemi Awolowo University, Ile-Ife, (M.Sc. Economics). Currently he is a PhD student in the Department of Economics, Obafemi Awolowo University, Nigeria where he concentrates on Financial Economics and Economics of Entrepreneurship. He is an Associate Member of both the Institute of Chartered Accountants of Nigeria (ACA) and Chartered Institute of Public Management (ACPM). He is the author of several articles published in local and international academic journals in the area of business, industrial, development and financial economics. He has contributed to several books in the field of economics and finance. In addition, his relevance in the field of accounting is evidenced by the books he has written in co-authorship, namely: Audit practice and Assurance Services (2015), Auditing and Investigations (2014); and Ethics in Accounting (2015). 
